\section{Molecular Response of Pulp Fibroblasts after Stimulation with Pulp Capping Materials}

Karin Cristina da Silva Modena ${ }^{1} \mathbb{D}$, Adriana Maria Calvoº ${ }^{(\mathbb{D}}$, Carla Renata

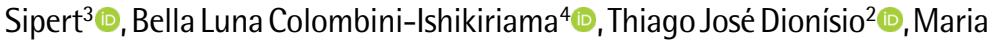

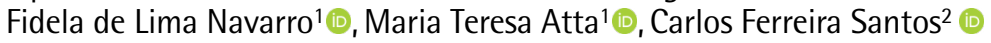

This in vitro study evaluated cell viability and metabolism, nitric oxide release and production of two chemokines and one cytokine by cultured human dental pulp fibroblasts (HDPF) in contact with two glass ionomer cements (Ketac Molar-KM and Vitrebond-VB), Single Bond (SB) and calcium hydroxide (Dycal-DY). Cultures of HDPF were established by means of an explant technique. The specimens were prepared under sterile conditions and in disks measuring $5 \mathrm{~mm} \times 2 \mathrm{~mm}$ obtained from a prefabricated mold and placed on a permeable membrane to avoid direct contact with the cells. Cytotoxicity was assessed by Trypan Blue exclusion method and 3-(4,5-dimethylthiazol-2-yl)-2,5-diphenyltetrazolium bromide (MTT) assay. Nitric oxide release in cell supernatant was detected by the Griess Method whereas stromal derived factor-1 alpha (SDF-1 $\alpha$ or CXCL12), chemokine (C-X-C motif) ligand 8 [Interleukin 8 (IL-8 or CXCL8)] and interleukin-6 (IL-6) were detected by ELISA. RT-qPCR was employed for gene expression analysis. Statistical analyses were performed by One-way ANOVA followed by Tukey's post hoc test for materials independent of the time, and Two-way ANOVA followed by Bonferroni correction test for the comparisons between materials and experimental time $(p<0.05)$. Cytotoxic tests showed significant differences only for DY. Protein levels and mRNA expression were significantly increased for IL-8 for both periods of time. IL-6 production increased when fibroblasts were stimulated by KM. SDF- $1 \alpha$ protein production and mRNA expression were not affected by any of the materials. There was a decrease in nitrate/nitrite levels only for KM. Although DY caused intense cell death and did not stimulate the production of the inflammatory mediators evaluated in this work, it is known that this event seems to be fundamental for the process of repair of the pulp tissue and formation of mineralized barrier. KM and VB increased production of proteins related to the inflammatory process, thus favoring tissue repair. Therefore, although these glass ionomer cements did not lead to large cell death, they should be used with caution.

\author{
'Department of Restorative \\ Dentistry, Endodontics and \\ Dental Materials, Bauru School \\ of Dentistry, USP - Universidade \\ de São Paulo, Bauru, SP, Brazil \\ ${ }^{2}$ Department of Biological \\ Sciences, Bauru School of \\ Dentistry, USP - Universidade de \\ São Paulo, Bauru, SP, Brazil \\ 3Department of Restorative \\ Dentistry, School of Dentistry, \\ USP - Universidade de São \\ Paulo, São Paulo, SP, Brazil \\ ${ }^{4}$ Department of Pediatric Dentistry, \\ Orthodontics and Public Health, \\ School of Dentistry, Bauru School \\ of Dentistry, USP - Universidade \\ de São Paulo, Bauru, SP, Brazil \\ Correspondence: Carlos Ferreira \\ Santos, Alameda Octávio Pinheiro \\ Brisolla, 9-75, 17012-191 Bauru, \\ SP, Brasil. Tel: +55-14-3235-8295. \\ e-mail: cfsantos@fob.usp.br
}

Key Words: cytotoxicity, dental materials, chemokines, cytokines, fibroblasts.

\section{Introduction}

Adequate restorative treatments are the main objective of restorative dentistry and they intend to re-establish the dental pulp homeostasis, thus maintaining tooth health. Choosing properly combination of pulp capping and restorative materials to accomplish a successful treatment is one of the main challenges faced by this dentistry field today. All materials used should satisfy some requirements such as to be similar to the dental structure concerning the biocompatibility as well as physical and mechanical properties. The effect of restorative materials together with remnant dentine thickness displays central attention considering the pulp vitality after restorative procedures. Therefore, biological effects of restorative materials on dental pulp cells should be considered, especially due to the large number of adhesive products and techniques becoming regularly available for the dental practice $(1,2)$. The protection of the dentin-pulp complex consists in the application of specific materials between the restorative material and the dentin to avoid additional aggression to the pulp tissue. Not every pulp reaction that may occur during pulp capping results in permanent damage to the pulp. Inflammation is generally considered a reparative inflammatory reaction in which all elements for repair are present.

The materials that can be used for this purpose are calcium hydroxide $(\mathrm{CH})$-based products $(3,4)$, glass ionomer cements (GICs) and adhesive systems (5-8). Calcium hydroxide cement $(\mathrm{CHC})$ is one of the most frequently chosen materials for direct and indirect pulp capping $(3,4)$. It is known for inducing mineralization, low toxicity and high $\mathrm{pH}$ that is responsible for its antibacterial function (9). In vivo, CHC induced a moderate inflammatory process, which was gradually reduced from the 7th to the 13th and 20th day (10). These inflammatory effects are characterized by tissue response that involves vascular permeability, soluble factors and migration of leukocytes (11). In this process, an important role is assigned to the 
release of cytokines, chemokines or leukotriene-B4 by resident cells in inducing the recruitment of leukocytes to the inflammatory site (12). CHC can induce an increase in the regulation of pro-inflammatory cytokines during the acute phase of inflammatory response and influence the regulation of anti-inflammatory cytokines (13). $\mathrm{CHC}$ is consistently indicated for direct pulp capping due to pulp vitality maintenance and mineralized barrier formation (14). The last, in turn, seems to be related to the necrotic effect caused by its high pH (12.5) (15), followed by cell proliferation and collagen deposition, which will attract mineral salts and form the calcified matrices (15). Despite the known role of the necrotic tissue in the pulp repair process, it is not completely understood the effect of released substances from $\mathrm{CHC}$ to the modulation of dental pulp cells function.

Resin-modified glass ionomer cements (RMGIC) were developed to overcome the problems of conventional glass ionomer cements such as the long setting time, technique sensitivity and low fracture resistance (16). However, monomers were incorporated as HEMA, bis-GMA and camphorquinone as photoinitiator. Due to its composition of $20 \%$ in volume of fluid, dentin can dissolve the RMGIC due to its tubular characteristic and presence of liquid. Consequently, its components can be released and diffused through dentinal tubules reaching the pulp and thus leading to an inflammatory process. Studies have shown that the inorganic ions concentration that are released by RMGIC and $\mathrm{GIC}$, such as $\mathrm{Sr} 2+, \mathrm{Al} 3+$ and $\mathrm{F}$ - are low to cause any cytotoxic effect. However, unpolymerized HEMA is released by RMGIC in the early $24 \mathrm{~h}$ after polymerization and this substance compromises RMGIC biocompatibility (17). Several studies demonstrate that RMGIC are cytotoxic to different cell types and tissues due to the release of HEMA $(5,6,17,18)$ and it causes serious damage to pulp cells $(1)$, that in turn can lead to immune responses in different degrees of severity resulting in pulp inflammation $(7,8)$.

Adhesive systems are basically composed of monomers such as bisphenylglycidyl dimethacrylate (BisGMA), urethane dimethacrylate (UDMA), triethylene glycol dimethacrylate (TEGDMA) and 2-hydroxyethyl methacrylate (HEMA). Conversion of monomers is incomplete during the polymerization of methacrylate-based adhesive systems. Thus, unreacted molecules are released to pulp tissue through dentinal tubules or pulp exposure (3). These substances are cytotoxic when placed in direct contact with fibroblasts. HEMA is one of the components that are released from dental adhesives (4), and rapidly diffuses through the dentin due to its low molecular weight and hydrophilicity. It is also known for preventing pulp cells differentiation into odontoblasts (5) and suppressing the growth of several cell types (4).
It has been reported that the high alkaline $\mathrm{pH}$ of $\mathrm{CH}$ solutions can solubilize and release some proteins and growth factors from dentin. These events may be responsible for pulp repair and hard tissue barrier formation, although due to its high $\mathrm{pH}, \mathrm{CH}$ induces a coagulation necrosis layer when in direct contact with pulp tissue. The incorporation of HEMA to the formulation of conventional glass ionomer cements and to the adhesive systems increases their toxic effects as a consequence and might trigger an inflammatory reaction (2). The present work aims to investigate the influence of these materials used in dentistry in the inflammatory response of cultured fibroblasts from human dental pulp of permanent teeth in relation to the expression and production of inflammation mediators.

The null hypotheses of the study were: 1 . There is no difference in the cell viability for the tested materials. 2 . There is no difference for Nitric Oxide (NO) levels for the tested materials. 3. There is no difference in production of SDF- $1 \alpha$, IL- 6 and IL- 8 for the tested materials. 4 . There is no difference in expression of SDF- $1 \alpha, \mathrm{IL}-6$ and IL-8 mRNA for the tested materials.

\section{Material and Methods}

\section{Culture of Human Dental Pulp Fibroblasts (HDPF)}

The experiments were conducted in accordance with the Declaration of Helsinki. Ethical approval was obtained prior to experiments from the local Ethics Committee for Human Research (\#137/2007). Under patient informed consent, one male and two female subjects ( $18-25$ years) donated three third molars, one of each patient. Dental pulp was removed under aseptic conditions and tissues were minced for fibroblasts cultures using an explant technique $(1,19,20)$.

Fragments of dental pulp were incubated for cell outgrowth in Dulbecco's modified Eagle's medium (DMEM) (Gibco, Invitrogen Corporation, Carlsbad, CA, USA) supplemented with 10\% fetal bovine serum (Gibco) and antibiotics $(100 \mu \mathrm{g} / \mathrm{mL}$ penicillin, $100 \mu \mathrm{g} / \mathrm{mL}$ streptomycin, $0.5 \mathrm{mg} / \mathrm{mL}$ amphotericin B - Invitrogen Corporation). Cultures were kept at $37^{\circ} \mathrm{C}$ in a humidified atmosphere of $5 \% \mathrm{CO}_{2}$ and $95 \%$ air. Cultures were maintained until the fibroblasts reached confluence with exchange of DMEM and 10\% FBS every two to three days. Experiments were performed using subcultured fibroblasts between the fourth and eighth passages. Phenotypic characterization of the HDPF was performed by a previous study by our group (19).

\section{Dental Materials Preparation}

Vitrebond (VB), Single Bond (SB), Ketac Molar (KM) (3M Espe, St. Paul, USA) and Dycal (DY) (Dentsply, Sirona, PA, USA) (Table 1) were chosen as tested pulp capping materials for this study, and were prepared under sterile 
conditions and in disks measuring $5 \mathrm{~mm} \times 2 \mathrm{~mm}$ obtained from a prefabricated mold $(21,22)$. VB and SB specimens were photoactivated with a quartz-tungsten-halogen lamp (Astralis 3, Ivoclar Vivadent) calibrated at $700 \mathrm{~mW} / \mathrm{cm}^{2}$ for the time recommended by the manufacturer; KM and DY were processed also according to the manufacturer's instructions. The surface of VB and SB were protected with a strip of polyester to prevent formation of the layer inhibited by oxygen. The specimens were placed on a permeable membrane (Maxicell $24 \mathrm{~W} 0.4 \mu \mathrm{m}$ ) to avoid direct contact with the cells (21). The control group for these materials was called CTW, consisting of culture medium, cells without stimulation and the permeable membrane.

\section{Fibroblast Stimulation}

Experiments were conducted in triplicate for each assay. HDPF were seeded at $5 \times 10^{4}$ cells/well in 24-well plates. Confluent cells had the medium changed for $1 \mathrm{~mL}$ of DMEM only or containing the diluted dental materials as described (VB, SB, KM and DY). Transwell inserts specimens were also placed over cells in DMEM. After 6 and $24 \mathrm{~h}$, supernatants were collected and stored at $-20{ }^{\circ} \mathrm{C}$ after centrifugation. The cells were submitted to cytotoxicity test or collected by trypsinization or Trizol ${ }^{\circledR}$ (Invitrogen Corporation) accordingly.

\section{Cell Viability and Cytotoxicity Assay -Tripan Blue and MTT}

After stimulation of human dental pulp fibroblasts for a 6 and $24 h$, the materials were removed and the cells washed with saline, removed from the plate by addition of trypsin $(100 \mu \mathrm{L})$, and neutralized with 10\% FBS DMEM $(300 \mu \mathrm{L})$. Cells were centrifuged at 1,200 $\mathrm{g}$ for $10 \mathrm{~min}$ at room temperature and resuspended in $200 \mu \mathrm{L}$ of $10 \%$ FBS DMEM. Then, they were detached, stained with 0.4\% Trypan

Table 1. Pulp capping materials composition

\begin{tabular}{lc}
\hline Material & Composition \\
\hline Dycal & $\begin{array}{c}\text { Base: ester glycol salicylate, calcium phosphate, } \\
\text { calcium tungstate, zinc oxide and mineral dyes. } \\
\text { Catalyst: ethyltoluene sulfonamide, } \\
\text { calcium hydroxide, zinc oxide, zinc } \\
\text { stearate and mineral dyes. }\end{array}$ \\
Vitrebond & $\begin{array}{c}\text { Powder: fluoraluminiosilicate and } \\
\text { canphoroquinone glass, liquid: polyalvenoic acid } \\
\text { copolymer, water, HEMA and photoactivator } \\
\text { BisGMA, HEMA, dimetacrylates, ethanol, } \\
\text { water, photoinitiator system, functional } \\
\text { copolymer of polyacrylic and polyalvenoic } \\
\text { acid methacrylate, silica nanoparticle } \\
\text { Ketac Molar }\end{array}$ \\
water, acrylic acid and maleic acid \\
copolymer, tartaric acid
\end{tabular}

Blue Solution (Sigma Aldrich, St. Louis, USA), and counted with a hemocytometer by using Dye exclusion method.

After removal of supernatants and inserts, $20 \mu \mathrm{L}$ of an MT [3-(4,5-dimethylthiazol-2-yl)-2,5-diphenyltetrazolium bromide] (Sigma-Aldrich, St Louis, EUA) solution ( $5 \mathrm{mg} /$ $\mathrm{mL}$ ) in phosphate buffered saline (PBS) were added to the cells or cell-free blank wells followed by $180 \mu \mathrm{L}$ of $10 \%$ FBS DMEM. Fibroblasts were incubated for $4 \mathrm{~h}$ at $37^{\circ} \mathrm{C}$ at standard conditions, in $5 \% \mathrm{CO}_{2}$, protected from light. MTT solution was then removed and replaced with 100 $\mu \mathrm{L}$ of isopropanol; the plate was incubated for $20 \mathrm{~min}$ at room temperature and the optical density of the wells was determined using a plate reader (FLUOstar Optima, BMG Labtech, Ortenberg, Germany) with wavelength set at 570 $\mathrm{nm}$, in which the absorbance reading was performed.

Nitric Oxide (NO) measurement

The Griess method was employed as previously described $(19,22)$. From the supernatant of the cells stimulated with the different materials, NO levels were measured by the nitrate/nitrite colorimetric assay. Aliquots of $50 \mu \mathrm{L}$ of each cell supernatant were added to a 96-well plate in duplicate. As negative control, 10\% FBS DMEM alone was tested. $25 \mu \mathrm{L}$ of 2\% sulfanilamide (Sigma-Aldrich) in 5\% phosphoric acid (Merck) were added to the wells and incubated for $10 \mathrm{~min}$. After that, $25 \mu \mathrm{L}$ of $0.2 \% \mathrm{~N}$-(1-naphthyl) ethylenediamine dihydrochloride (NED) (Sigma-Aldrich) in distilled water were added and samples were incubated for $10 \mathrm{~min}$ protected from light. Finally, the absorbance was measured at $530 \mathrm{~nm}$. Calculation of nitrite concentration was based on the optical density of a two-fold serially diluted NaNO2 solution (Sigma-Aldrich).

\section{Cytokines Detection}

The production of SDF- $1 \alpha$, IL- 6 and IL- 8 was measured in the cell supernatants by means of enzyme-linked immunosorbent assay (ELISA) (RED systems, Minneapolis, USA) according to the manufacturer's instructions. Briefly, capture antibodies were incubated followed by samples or standards. Next, the respective biotin-conjugated detection antibodies were incubated. Colorimetric reaction was observed by the presence of streptavidin-conjugated peroxidase and the added substrate. Absorbance was measured at $450 \mathrm{~nm}$ (ELISA microplate reader, Bio-Rad, Hercules, CA, USA).

\section{mRNA Expression}

After removal of supernatants, total RNA was extracted from $5 \times 104$ cells using $1 \mathrm{~mL}$ of Trizol ${ }^{\circledR}$ (Invitrogen Corporation). Total RNA was isolated by guanidine isothiocyanate phenol-chloroform extraction method. Briefly, homogenization, chloroform extraction, isopropanol precipitation, and 75\% (volume/volume) ethanol washing 
of precipitated RNA were performed (23). Total RNA was quantified in a spectrophotometer (Nanodrop ${ }^{\circledR}$, Thermo Scientific, Wilmington, USA) at the wavelengths of 280 and $260 \mathrm{~nm}$.

To avoid the possibility of contamination by genomic DNA, $1 \mu \mathrm{g}$ of total RNA was incubated with gDNAse Wipeout Buffer (Qiagen, Germantown, USA) for 2 min at 420C.

Reverse transcription was performed using QuantiTect Reverse Transcription Kit (Qiagen, Hilden, Alemanha) according to manufacturer's instructions. Synthetic cDNAs served as the templates for targets amplification by means of quantitative polymerase chain reaction (qPCR) with Taqman ${ }^{\circledR}$ Gene Expression Mastermix reagents (Applied Biosystems, Life Technologies, USA) (2x), Taqman ${ }^{\circledR}$ assays (20x) (SDF-1 $\alpha$ : Hs00171022_m1, IL-6 Hs00985639_m1 and IL-8: Hs00174103), primers and probes as determined by the manufacturer, with a final reaction volume of $5 \mu \mathrm{L}$. The amplification reaction comprised $2 \mathrm{~min}$ at $50{ }^{\circ} \mathrm{C}, 10 \mathrm{~min}$ at $95^{\circ} \mathrm{C}, 45$ cycles of $15 \mathrm{~s}$ at $95^{\circ} \mathrm{C}$ and 1 minute at $60{ }^{\circ} \mathrm{C}$, as recommended by the manufacturer. The results were analyzed based on the value of cycle threshold (Ct), corresponding to the number of cycles after which the amplification reaches a given threshold that allows the quantitative analysis of the expression of the evaluated gene. The means of the Ct values of duplicate measures were used to calculate the expression of the target gene, with normalization in relation to an internal control (RPL13A, F:5'-CCGCTCTGGACCGTCTCAA-3', R: 5'-CCTGGTACTTCCAGCCAACCT-3', Probe: 5'- (VIC)TGACGGCATCCCACCGCCCT-(TAMRA)-3', and analyzed in comparison to a sample from control group (1) of unstimulated cells, using the formula 2- $\Delta \Delta$ Ct. Data were normalized based on an endogenous control.

\section{Statistical Analyses}

Statistical analyses were performed using Graph Pad Prism 5.0 (GraphPad Software, La Jolla, CA, USA). Statistically significant differences were determined by One-way ANOVA followed by Tukey's post hoc test for materials independent of the time, and Two-way ANOVA followed by Bonferroni correction test for the comparisons between materials and experimental time. The significance level was set at $p<0.05$.

\section{Results}

Trypan Blue and MTT results showed significant decrease in cell viability at the 24-h time period with less than 10\% of viable cells for DY $(p<0.05)$ when compared to control (Fig. 1A). The value of MT decreased to approximately 28.5\% (Fig. 1B). Considering the result of cell viability, subsequent analysis for gene expression and production of cytokines in HDPF stimulated with DY will not be presented.
$\mathrm{VB}, \mathrm{SB}$ and KM did not alter gene expression or SDF- $1 \alpha$ production (Fig. 2). VB significantly increased either gene expression or production of IL-8 at both time periods, and KM stimulated its production only at the time period of $24 \mathrm{~h}(\mathrm{p}<0.05)$ (Fig. 3).

IL-6 production was increased when fibroblasts were stimulated by $\mathrm{KM}$, at $6 \mathrm{~h}$, compared to the control group $(p<0.05)$ and the other materials did not affect either gene expression (Fig. 4A) or IL-6 production (Fig. 4B).

Regarding NO release, the only statistically significant difference $(\mathrm{p}<0.05)$ was observed for $\mathrm{KM}$, in which there was a decrease in nitrate/nitrite levels when compared to the CTW control group in the 6-h time period (Fig. 5).

\section{Discussion}

According to the results obtained in the present study, all the null hypotheses were rejected. Cell viability was drastically affected when calcium hydroxide (DY) stimulated human dental pulp fibroblasts (HDPF), which is expected since its high $\mathrm{pH}$ induces a coagulation necrosis layer (2). $\mathrm{VB}, \mathrm{SB}$ and $\mathrm{KM}$ did not show significant decreases in HDPF viability, but increased gene expression and production of IL-8 and IL-6.

Biocompatibility and cytotoxicity tests are not only essential but also recommended for materials used in
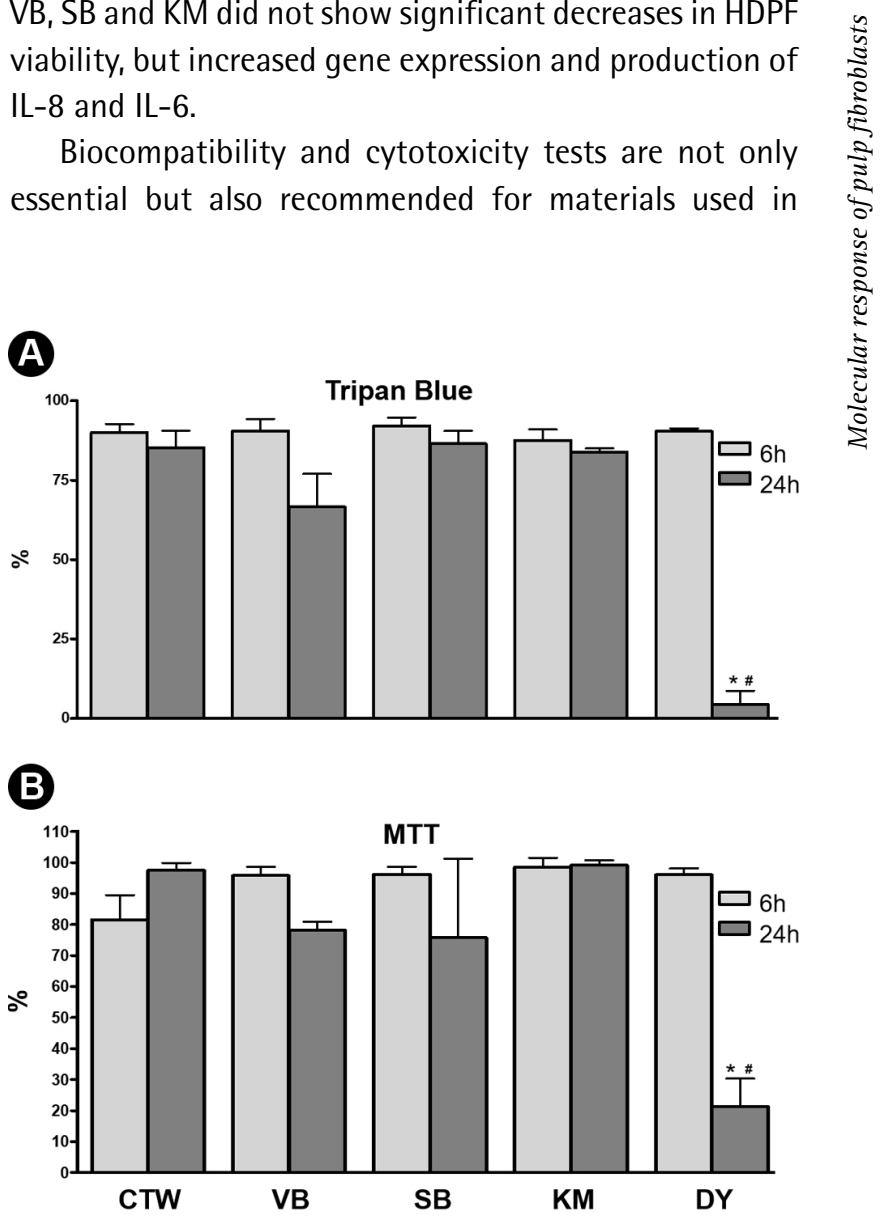

Figure 1. Cell viability assay (A: Trypan Blue and B: MTT) of cultured human dental pulp fibroblasts when stimulated by Vitrebond (VB), Single Bond (SB), Ketac Molar (KM) and Dycal (DY) compared to the group CTW control. Values are presented as percentage of live cells within $24 \mathrm{~h} .{ }^{*}$ Statistically significant difference in relation to the control, $\mathrm{p}<0.05$. 
healthcare. The American Dental Association (ADA) recommends a sequence of biocompatibility testing for dental materials (24). The string consists of initial tests, secondary and use. Initial tests are conducted in vitro for cytotoxicity and mutagenesis for the dental materials and their components. The importance of studying the protective effects of the dentin-pulp complex lies on improving the use and indications of materials in order to avoid severe pulp damage. The dentin-pulp complex is able to adapt to a series of stimuli, invoking a defense response to maintain vitality.

Biocompatibility may be defined as the ability of the material to perform the function that was proposed without causing undesirable effects (25) as allergic, inflammatory or toxic reactions when in contact with tissue or organic fluids. Once placed in contact with living tissues, the material will generate a biological response and the cytotoxicity may result in metabolic changes until cellular death. Cytotoxicity tests are the first step to ensure the biocompatibility of a material (26). The tests used to evaluate cytotoxicity include the trypan blue exclusion assay and succinic dehydrogenase (SDH) enzyme production by 3-(4,5-dimethythiazol-2yl)-2,5-diphenyl tetrazolium bromide (MTT) assay.

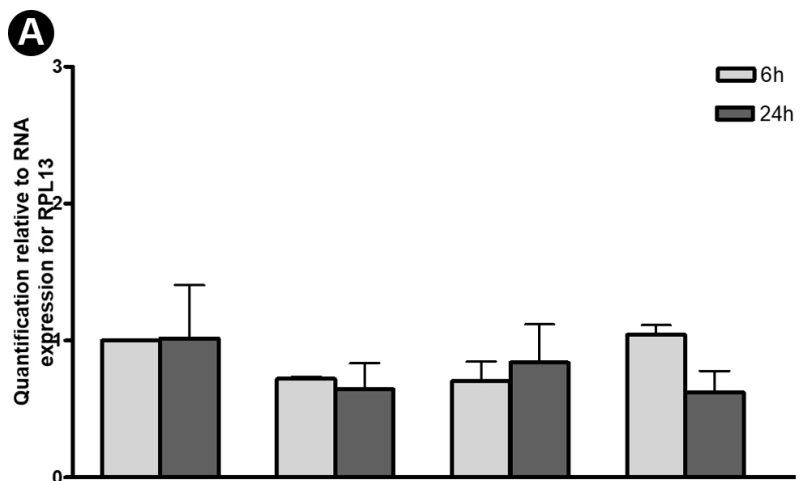

\section{B}

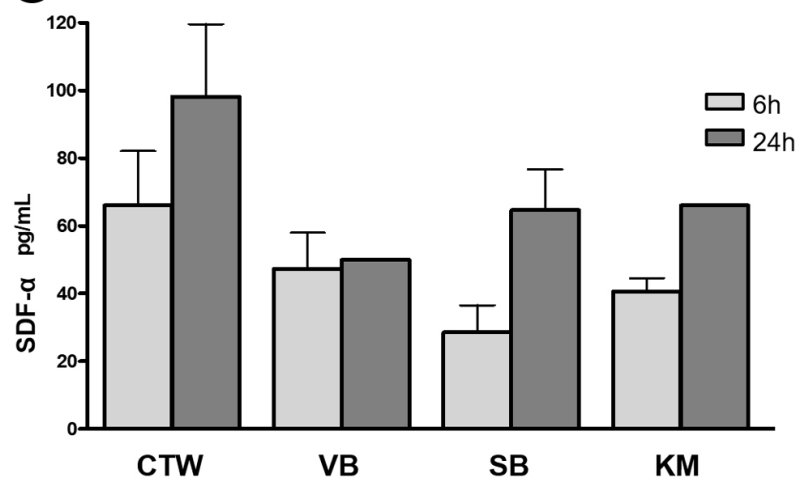

Figure 2. Expression (A) and in vitro production (B) of SDF-1 $\alpha$ mRNA coding for cultured human dental pulp fibroblasts stimulated by Vitrebond (VB), Single Bond (SB) and Ketac Molar (KM) for 6 and 24 h. Values are representative of means \pm standard deviation. $p<0.05$.
Trypan Blue results for DY showed more than 90\% of viability loss at the time of $24 \mathrm{~h}, \mathrm{MTT}$ showed the decreases to approximately $28.5 \%$, and that was one of the limitations of the study, making it impossible to test this material largely used in dental practice in the subsequent experiments. These data corroborate the knowledge about the occurrence of tissue necrosis under $\mathrm{CHC}$ direct contact. However, at this context, the restricted necrotic area might mimic the basal membrane between primary ameloblasts and odontoblasts at cell differentiation along odontogenesis. Also, due to its high $\mathrm{pH}$, the release of growth factors such as Transforming Growth Factor- $\beta$ may occur. This, in turn, is suggested as the mechanism responsible for the pulp repair and formation of mineralized barrier (27-31).

SDF- $\alpha$ is closely related to homeostasis of different tissues, such as is pulp tissue, where it is involved in the processes of mineralization, neovascularization and chemotaxis and recruitment of stem cells. However, in the inflammatory process the expression of this chemokine may be decreased $(1,32)$. In this study, the pulp capping materials tested did not alter either the expression or production of SDF- $\alpha$, thus showing that the tested materials were not
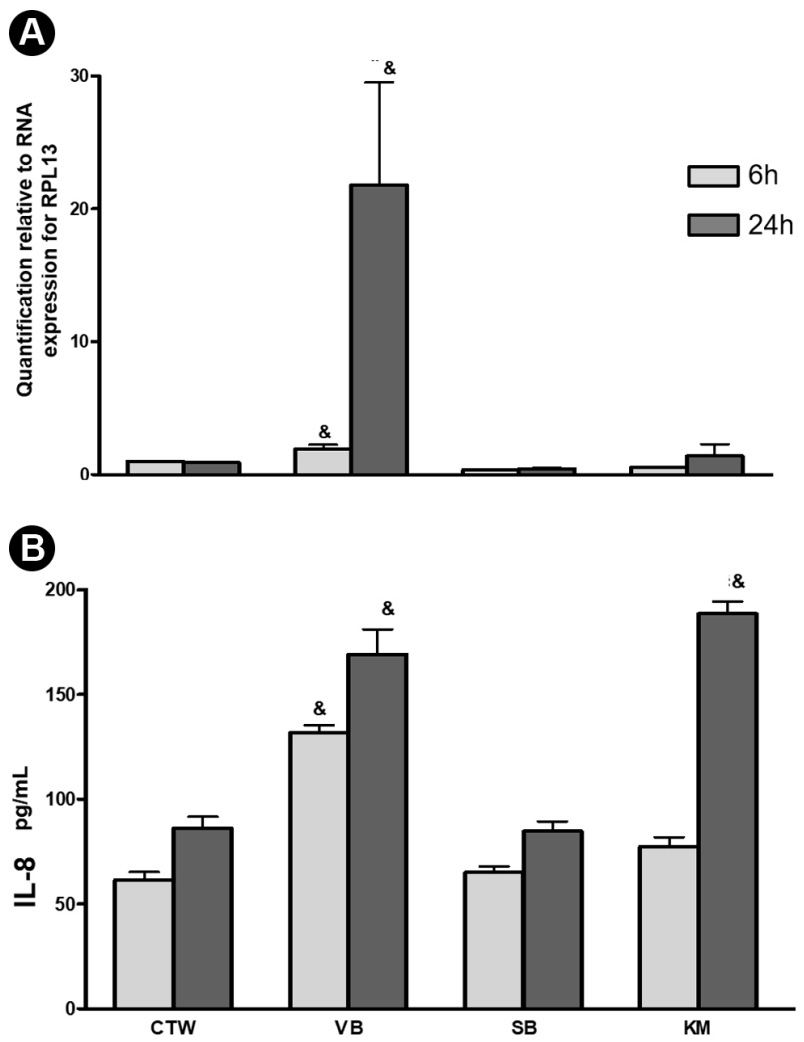

Figure 3. mRNA expression (A) and in vitro production (B) for IL-8 by cultured human dental pulp fibroblasts stimulated by Vitrebond (VB), Single Bond (SB) and Ketac Molar (KM) for $24 \mathrm{~h}$. Values are representative of means \pm standard deviation. $\mathrm{E}>\mathrm{CTW}, \mathrm{p}<0.05$. 
relevant inflammatory triggers for such chemokine in the inflammatory process.

IL-6 and IL-8 are fundamental proteins for the understanding of the inflammatory process. IL-6 has been associated with immunopathology of periodontal tissue (23). The release of IL-8 occurs mainly by the presence of LPS, mediated by IL-1, very present mainly in acute inflammatory reactions, thus amplifying this process $(1,20,21)$. Morandini et al showed that in inflammatory conditions also induced by LPS, the levels of IL-6 in gingival fibroblasts were significantly higher than in periodontal fibroblasts (21), but this role in pulp tissue was not evaluated. In the present study, where the main objective was to measure these proteins after pulp fibroblast stimulation with several pulp capping materials, IL-6 production was increased when fibroblasts were stimulated by Ketac Molar (KM) at $6 \mathrm{~h}$ compared to the control group. IL-8 production was detected in both periods, 6 and $24 \mathrm{~h}$, at higher levels than the control group for VB and KM at 6h. VB significantly increased the gene expression and the production of IL-8 in both periods. It has been demonstrated that the treatment of human dental pulp mesenchymal cells with resinous materials increased the production of inflammatory

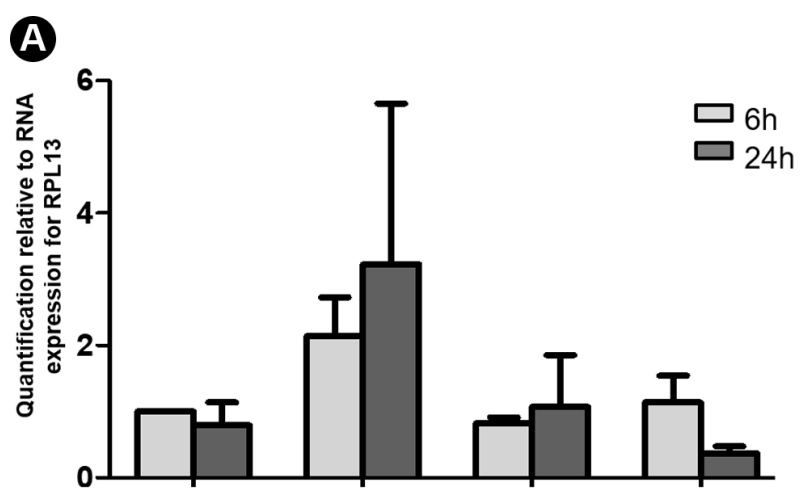

B

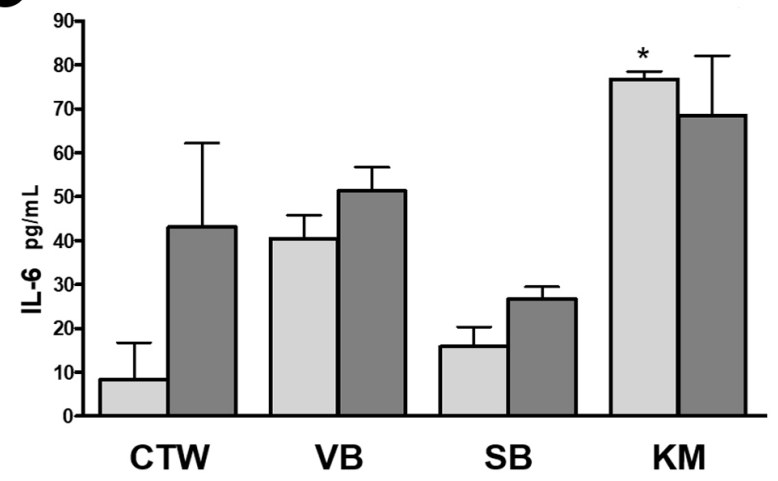

Figure 4. mRNA expression of (A) and in vitro production (B) for IL-6 by cultured human dental pulp fibroblasts stimulated by Vitrebond (VB), Single Bond (SB) and Ketac Molar (KM) for $24 \mathrm{~h}$. Values are representative of means \pm standard deviation. * $>$ CTW at $6 \mathrm{~h}, \mathrm{p}<0.05$. mediators, such as IL-6 and IL-8, leading to the conclusion that the release of proinflammatory cytokines by pulp mesenchymal cells could promote the regeneration of the dentin-pulp complex $(7,31)$.

Nitric oxide (NO) is an intracellular messenger molecule of great importance in physiological and pathological processes. NO is involved in the control of cell growth, differentiation, apoptosis, vasodilation and neurotransmission. NO, in high concentrations, can act as a potent cytotoxic molecule causing damage to tissues. Induction of iNOS isoform can inhibit fibroblasts proliferation and induce cell death, which contributes to the imbalance between destruction and tissue repair (32). This occurs in inflammatory processes, in which there is an increase in NO synthesis, as demonstrated in cases of pulpitis (33). NO, in small amounts, regulates muscle relaxation and protects against leukocyte adhesion and platelets in the blood vessel wall and can be considered a protective molecule and anti-inflammatory. The present study showed that the production was decreased when the human dental pulp fibroblasts were stimulated by $\mathrm{KM}$, which is composed of powder and liquid that when mixed initiate the acid/base reaction. KM is widely used in dentistry due of its biocompatibility, antibacterial properties, adhesion and coefficient of linear thermic expansion similar to the tooth structure and fluoride release. Fluoride release occurs intensely in the first 24 to $48 \mathrm{~h}$, remaining in lower concentration for long periods of time. The presence of fluoride may have caused the decrease in NO production. $\mathrm{NO}$ activity in plasma decreased when rabbits were exposed to high concentration of fluoride in water, leading to the conclusion that high concentrations of fluoride can cause a disorder in the metabolism. Although many studies reported an increase in NO production in different tissues and cell types when in contact with fluoride $(34,35)$, the comparison should be performed with caution because the fluoride concentration used in these studies is higher than in KM.

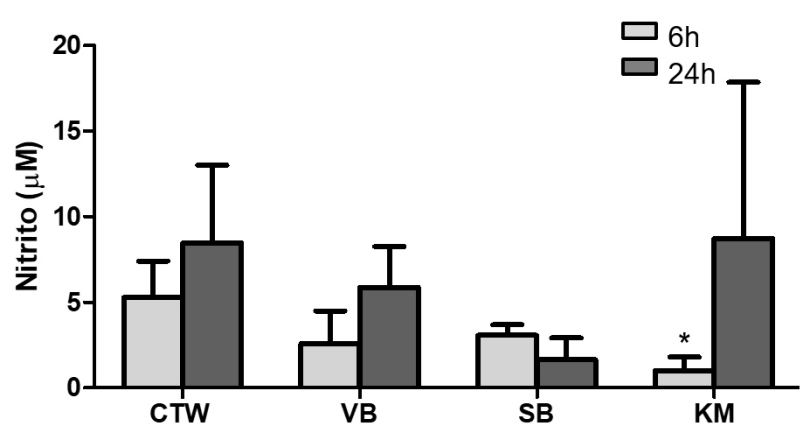

Figure 5. Amount of nitrite produced by cultured human dental pulp fibroblasts stimulated by Vitrebond (VB), Single Bond (SB), Ketac Molar (KM) and Dycal (DY) for 6 and $24 \mathrm{~h}$. Values are representative of means \pm standard deviation. ${ }^{*}<\mathrm{CTW}, \mathrm{p}<0.05$. 
Although cell viability tests demonstrated that experiments with DY should not be carried out, further research with this material should be performed, as it is often used in dental clinics.

When comparing the pulp capping materials used in this study, DY was significantly more cytotoxic, decreasing cell metabolism and causing intense cell death. The glass ionomer cements used, $\mathrm{VB}$ and $\mathrm{KM}$, increased the production of proteins related to the inflammatory process, which may lead to the recruitment of cells and molecules to the site of the aggression and consequently favor the tissue repair. Therefore, although these glass ionomer cements did not lead to large cell death, they should be used with caution.

\section{Resumo}

Este estudo avalia in vitro a viabilidade e metabolismo celular, a liberação de óxido nítrico e a produção de duas quimiocinas e uma citocina por fibroblastos de polpa dentária humana em cultura (FPDH) em contato com dois cimentos de ionômero de vidro (Ketac Molar-KM e VitrebondVB), Single Bond (SB) e hidróxido de cálcio (Dycal-DY). As culturas de FPDH foram estabelecidas por meio de uma técnica de explante. As amostras foram preparadas em condições estéreis e em discos de 5 $\mathrm{mm} \times 2 \mathrm{~mm}$, obtidas de um molde pré-fabricado e colocadas em uma

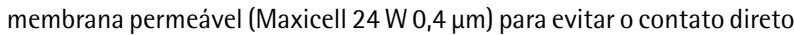
com as células. A citotoxicidade foi avaliada pelo método de exclusão $\dot{\Xi}$ de Trypan Blue e pelo ensaio de MTT. A liberação de óxido nítrico no sobrenadante celular foi detectada pelo método Griess, enquanto fator 1 derivado do estroma (SDF-1 $\alpha$ ou CXCL12), interleucina-8 (IL-8 ou CXCL8) and interleucina-6 (IL-6) foram detectados por ELISA. RT-qPCR foi empregada para análise de expressão gênica. As análises estatísticas foram realizadas por ANOVA a 1 critério, seguida pelo pós-teste de Tukey para os materiais independentes do tempo, e ANOVA a 2 critérios, seguida pelo teste de correção de Bonferroni para comparações entre materiais e tempo experimental $(p<0,05)$. Os testes citotóxicos mostraram diferenças significativas apenas para DY. Os niveis da proteina e a expressão de RNAm para IL-8 aumentaram significativamente para ambos os tempos estudados. A produção de IL-6 aumentou quando os fibroblastos foram estimulados por KM. A produção da proteina e a expressão de RNAm para SDF-1 $\alpha$ não foram afetadas por nenhum dos materiais. Houve uma diminuição nos níveis de nitrato/nitrito apenas para KM. Embora o DY tenha causado intensa morte celular e não tenha estimulado a produção dos mediadores inflamatórios avaliados neste trabalho, sabe-se que esse evento parece ser fundamental para o processo de reparo do tecido pulpar e formação de barreira mineralizada. Os cimentos de ionômero de vidro utilizados aumentaram a produção de proteinas relacionadas ao processo inflamatório, favorecendo a reparação tecidual e, portanto, esses materiais, embora não causem grande morte celular, devem ser utilizados com cautela.

\section{Acknowledgements}

This study was funded by FAPESP (Grants 2005/60167-0, 2010/012301 and 2015/03965-2 to CFS). This study was funded in part by the Coordenação de Aperfeiçoamento de Pessoal de Nivel Superior - Brasil (CAPES) - Finance Code 001.

\section{References}

1. Modena K, Calvo A, Sipert C, Dionisio T, Navarro M, Atta M, et al. Dental pulp fibroblasts response after stimulation with hema and adhesive system. Braz Dent J 2018;29:1-8.

2. Modena KC, Casas-Apayco LC, Atta MT, Costa CA, Hebling J, Sipert $C R$, et al. Cytotoxicity and biocompatibility of direct and indirect pulp capping materials. J Appl Oral Sci 2009;17:544-554

3. Farhad A, Mohammadi Z. Calcium hydroxide: a review. Int Dent J 2005;55:293-301.

4. Holland R, Souza V, Nery MJ, Bernabé PFE, Filho JA, Júnior ED, et al. Calcium salts deposition in rat connective tissue after the implantation of calcium hydroxide-containing sealers. J Endod 2002;28:173-176.

5. Pereira JC, Segala AD, Costa CA. Human pulpal response to direct pulp capping with an adhesive system. Am J Dent 2000;13:139-147.

6. Schroder U. Effects of calcium hydroxide-containing pulp-capping agents on pulp cell migration, proliferation, and differentiation. J Dent Res 1985;64:541-548.

7. Burke FJ, Fleming GJ, Owen FJ, Watson DJ. Materials for restoration of primary teeth: 2 . glass ionomer derivatives and compomers. Dent Update 2002;29:10-17.

8. Geurtsen W. Biocompatibility of resin-modified filling materials. Crit Rev Oral Biol Med 2000;11:333-55.

9. Le Clerc J, Tricot-Doleux S, Pellen-Mussi P, Perard M, Jeanne S, Perez F. Expression of factors involved in dental pulp physiopathological processes by nemotic human pulpal fibroblasts. Int Endod J 2018;51:e94-e106.

10. Rakich DR, Wataha JC, Lefebvre CA, Weller RN. Effect of dentin bonding agents on the secretion of inflammatory mediators from macrophages. J Endodon 1999;25:114-117.

11. Hanks CT, Wataha JC, Parsell RR, Strawn SE, Fat JC. Permeability of biological and synthetic molecules through dentine. J Oral Rehabil 1994;21:475-487.

12. Geurtsen W, Lehman F, Spahl W, Leyhausen G. Cytotoxicity of 35 dental resin composite monomers/additives in permanent $3 \mathrm{t} 3$ and three human primary fibroblast cultures J Biomed Mater Res 1998;41:47480.

13. About I, Bottero MJ, de Denato P, Camps J, Franquin JC, Mitsiadis TA. Human dentin production in vitro. Exp Cell Res 2000;258:33-41.

14. Sipert $C R$, Moraes IG, Bernardinelli N, Garcia RB, Bramante $C M$, Gasparoto $\mathrm{TH}$, et al. Heat-killed enterococcus faecalis alters nitric oxide and $\mathrm{Cxc} 12$ production but not $\mathrm{Cxcl} 8$ and $\mathrm{Ccl} 3$ production by cultured human dental pulp fibroblasts. J Endod 2010;36:91-94.

15. Sipert CR, Morandini AC, Modena KC, Dionisio TJ, Machado MA, Oliveira $\mathrm{SH}$, et al. $\mathrm{Ccl} 3$ and $\mathrm{Cxcl} 12$ production in vitro by dental pulp fibroblasts from permanent and deciduous teeth stimulated by Porphyromonas Gingivalis Lps. J Appl Oral Sci 2013;21:99-105.

16. Faccioli LH, Souza GEP, Cunha FQ, Poole S, Ferreira SH. Recombinant interleukin-1 and tumor necrosis factor induce neutrophil migration "in vivo" by indirect mechanisms. Agents Actions 1990;30:344-349.

17. Reyes-Carmona JF, Santos AR, Figueiredo CP, Felippe MS, Felippe WT, Cordeiro MM. In vivo host interactions with mineral trioxide aggregate and calcium hydroxide: inflammatory molecular signaling assessment. J Endod 2011;37:1225-1235.

18. de Souza Costa CA, Hebling J, Garcia-Godoy F, Hanks CT. In vitro cytotoxicity of five glass-ionomer cements. Biomaterials 2003;24:3853-3858.

19. Mantellini MG, Botero TM, Yaman P, Dennison JB, Hanks CT, Nor JE. Adhesive resin induces apoptosis and cell-cycle arrest of pulp cells. J Dent Res 2003;82:592-596.

20. Yoshino P, Nishiyama CK, Modena KC, Santos CF, Sipert CR. In vitro cytotoxicity of white $\mathrm{mta}$, mta fillapex(r) and portland cement on human periodontal ligament fibroblasts. Braz Dent J 2013;24:111-116.

21. Morandini AC, Sipert CR, Gasparoto TH, Greghi SL, Passanezi E, Rezende $M L$, et al. Differential production of macrophage inflammatory protein-1 alpha, stromal-derived factor- 1 , and II- 6 by human cultured periodontal ligament and gingival fibroblasts challenged with lipopolysaccharide from P. Gingivalis. J Periodontol 2010;81:310-317.

22. Craig RG. Restorative dental materials. St. Louis: Mosby-Year Book Inc; 1997.

23. Williams D. Revisiting the definition of biocompatibility. Med Device Technol 2003;14:10-13.

24. Wataha JC. Priciples of biocompatibility for dental practioners. J Prothet Dent 2001;86:203-209.

25. Grobler SR, Olivier A, Moodley D, Kotze TWW. Cytotoxicity of two concentrations of a dentine bonding agent on mouse 3 t 3 and human 
pulp fibroblast cell-lines. SADJ 2004;59:368-372.

26. Hebling J, Giro EM, Costa CA. Biocompatibility of an adhesive system applied to exposed human dental pulp. J Endod 1999;25:676-682.

27. Holland R. Histochemical response of amputed pulps to calcium hydroxide. Rev Bras Pesq Med Biol 1971;4:83-95.

28. Smith AJ, Garde C, Cassidy N, Ruch IV, Lesot H. Solubilization of dentine extracellular matrix by calcium hydroxide. J Dent Res 1995;74:829.

29. Tjäderhane L. The Mechanism of pulpal wound healing. Aust Endod J 2002;28:68-74.

30. Jiang HW, Ling JQ, Gong $\mathrm{OM}$. The expression of stromal cell-derived factor 1 (Sdf-1) in inflamed human dental pulp. J Endod 2008;34:13511354.

31. Trubiani 0, Cataldi A, De Angelis F, D'Arcangelo C, Caputi S. Overexpression of Interleukin-6 and -8, cell growth inhibition and morphological changes in 2-hydroxyethyl methacrylate-treated human dental pulp mesenchymal stem cells. Int Endod J 2012:45:1925.

32. Kendall HK, Marchal RI, Bartold PM. Nitric oxide and tissue destruction. Oral Dis 2002;7:2-10

33. Di Nardo Di Maio F, Lohinai Z, D'Arcangelo C, De Fazio PE, Speranza L, De Lutiis MA, et al. Nitric oxide synthase in healthy and inflamed human dental pulp. J Dent Res 2004;83:312-316.

34. Bergandi L, Aina V, Malavasi G, Morterra C, Ghigo D. The toxic effect of fluoride on Mg-63 osteoblast cells is also dependent on the production of nitric oxide. Chem Biol Interact 2011;190:179-186.

35. Inkielewicz-Stepniak I, Czarnowski W. Oxidative stress parameters in rats exposed to fluoride and caffeine. Food Chem Toxicol 2010;48:1607-1611. 